\title{
PENYULUHAN DAN PELATIHAN PEMBUATAN SABUN HERBAL ALAMI (INOVASI PRODUK KREATIF MILLENIAL FOR ENTREPRENEUR)
}

\author{
Dewi Sartika ${ }^{*}$ \\ Amanda Patappari² \\ Asriyanti Syarif ${ }^{3}$ \\ 1*3Program Studi Agribisnis, Fakultas Pertanian, Universitas Muhammadiyah Makassar \\ ${ }^{2}$ Program Studi Agroteknologi, Fakultas Pertanian, Universitas Muhammadiyah Makassar \\ dewi.sartika@unismuh.ac.id $\left.1^{*}\right)$ \\ firmansyahamanda20@gmail.com ${ }^{2)}$ \\ asriyanti.syarif@gmail.com ${ }^{3}$ )
}

\begin{abstract}
Kata Kunci:
Inovasi, Produk, Kreatif, Sabun, Herbal
\end{abstract}

\begin{abstract}
Abstrak: Kegiatan pengabdian kepada masyarakat yang dikemas dalam bentuk penyuluhan dan pelatihan pembuatan sabun herbal alami merupakan salah satu upaya untuk meningkatkan inovasi dan kreatifitas kaum millennial muda Makassar dalam melihat potensi bisnis dari handmade sabun herbal alami. Tujuan dan target spesifik yang ingin dicapai adalah milenial muda mampu berkreasi dan menghasilkan sabun herbal alami yang unik, menarik dengan menonjolkan fungsionalitas sabun sehingga menghasilkan peningkatan nilai ekonomi, nilai guna, dan daya tarik sehingga bisa menjadi ciri khas produk dan menjadi pembeda dengan produk sabun herbal lainnya yang beredar dipasaran. Kegiatan Penyuluhan dan Pelatihan diadakan secara virtual dan diikuti oleh 126 peserta. Materi penyuluhan disajikan dengan memaparkan keunggulan handmade sabun herbal alami dengan jenis sabun komersial lainnya, pengaplikasian kreativitas dan inovasi dalam mengembangkan produk, dan potensi pengembangan bisnis handmade sabun herbal alami. Kegiatan pelatihan dilakukan dengan menunjukkan tahapan dan teknik pembuatan handmade sabun herbal alami dengan varian sereh wangi, kopi, dan arang aktif. Kegiatan penyuluhan dan pelatihan pembuatan handmade sabun herbal alami terlaksana dengan baik, ketertarikan peserta terhadap penyajian materi dan pelatihan ditunjukkan melalui proses diskusi yang atraktif. Hasil survey kepuasan peserta menunjukkan bahwa kegiatan yang dilaksanakan sangat menarik, mampu mengembangkan ide kreatif dan bermanfaat bagi para peserta dalam menambah pengetahuan, pengalaman dan keterampilan menjadi millennialpreneur.
\end{abstract}

Published by:

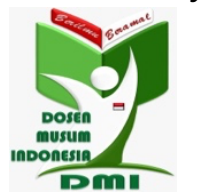

Copyright (C) 2021 The Author(s)

This article is licensed under CC BY 4.0 License

\section{(cc) $\mathrm{Br}$}

https://dmi-journals.org/jai 


\section{Pendahuluan}

Indonesia merupakan negara yang kaya akan varietas tanaman herbal yang berpotensi untuk dikembangkan menjadi bahan baku pada berbagai industri seperti, farmasi, makanan, minuman, kosmetik, perawatan tubuh dan lain sebagainya (Hakim 2015). Tanaman herbal merupakan jenis tamanam yang mengandung senyawa aktif yang mampu menghasilkan sifat fungsional tertentu sehingga banyak dimanfaatkan sebagai pengobatan alternatif untuk mencegah atau mengobati berbagai penyakit (Mulyani et al. 2016). Ketersediaan ragam bahan baku yang melimpah serta keunikan sifat fungsional dari masing-masing tanaman menjadi suatu potensi pengembangan produk inovatif yang mengikuti trend pemanfaatan bahan alami (back to nature) yang memberikan beberapa keuntungan antara lain relatif lebih murah, memberikan efek samping yang sangat kecil dibandingkan dengan menggunakan bahan kimia sintetik, bersifat ramah lingkungan, serta peluang pasar dari produk herbal yang semakin meningkat tiap tahunnya.

Diversifikasi produk herbal diperlukan untuk menghasilkan produk yang lebih variatif, inovatif, berdayaguna, bernilai ekonomi tinggi dan mengikuti trend kebutuhan konsumen saat ini. Pemanfaatan tanaman herbal masih sangat terbatas untuk produk kebersihan seperti sabun. Sabun herbal merupakan jenis sabun yang dibuat dengan menambahkan ekstrak herbal yang mengandung senyawa aktif sehingga memberikan kebaikan bahan alami dalam menutrisi kulit. Melimpahnya bahan baku, modal usaha yang relatif kecil, teknologi produksi yang sederhana dan mudah untuk diterapkan menjadi pertimbangan menarik pada aspek produksi sabun herbal alami. Hal ini membuka peluang usaha yang sangat menarik bagi millennial untuk arah pengembangan bisnis handmade sabun herbal alami.

Bisnis handmade sabun herbal alami sangat cocok di kerjakan oleh generasi millennial yang menjadi tulang punggung dalam perekonomian karena mereka cenderung lebih produktif, kreatif, inovatif, memiliki semangat kerja yang tinggi serta lebih visioner dalam melihat peluang. Millenial Muda Makassar sebagai mitra dalam kegiatan Pengabdian Kepada Masyarakat (PKM) mayoritas beranggotakan mahasiswa dan pelajar dari Makassar yang memiliki tingkat kebutuhan dan ketertarikan yang tinggi dalam mengembangkan potensi diri sebagai entrepreneur kreatif.

\section{Luaran Kegiatan}

Rangkaian kegiatan PKM dirancang untuk menghasilkan luaran yang telah ditargetkan, yaitu meningkatkan pengetahuan,keterampilan dan kreativitas mitra dalam pembuatan handmade sabun herbal alami dengan inovasi fungsionalitas berbagai jenis sabun..

\section{Metode Pelaksanaan}

\section{Pembuatan Handmade Sabun Herbal Alami}

Bahan - bahan yang digunakan dalam pembuatan handmade sabun herba alami adalah sebagai berikut: $\mathrm{NaOH}$, aquades, minyak kelapa, minyak kelapa sawit, minyak canola, minyak sereh wangi, arang aktif dan bubuk kopi. Sedangkan untuk peralatan menggunakan hand mixer, timbangan, gelas ukur, wadah, pipet tetes, spatula, cetakan silikon. 
Prosedur kerja pembuatan handmade sabun herbal alami dengan memodifikasi metode dari Rabani (2019). Berikut adalah tahapan prosedur pembuatan sabun herbal alami:

1. Larutan $\mathrm{NaOH}$ dibuat dengan melarutkan $115 \mathrm{~g} \mathrm{NAOH}$ kedalam $250 \mathrm{~g}$ aquades, aduk sampai larut dan dinginkan.

2. Larutan Minyak dibuat dengan mencampurkan $240 \mathrm{~g}$ minyak kelapa sawit, $240 \mathrm{~g}$ minyak kelapa dan 320g minyak canola.

3. Campurkan Larutan $\mathrm{NaOH}$ kedalam larutan minyak secara perlahan-lahan, aduk dengan menggunakan hand mixer selama 2 menit.

4. Tambahkan minyak essensial ataupun ekstrak herbal lainnya kedalam adonan, lanjutkan pengadukan hingga adonan menjadi sedikit kaku dan meninggalkan jejak.

5. Tuang adonan kedalam cetakan, kemudian semprotkan alcohol 99\% kepermukaan adonan, kemudian adonan disimpan pada suhu ruang selama 2-3 hari.

6. Setelah adonan mengeras, sabun siap dipotong-potong menjadi beberapa bagian, selanjutnya disimpan kembali pada suhu ruang selama 3-4 minggu sebelum sabun digunakan.

\section{Penyuluhan dan Pelatihan Pembuatan Handmade Sabun Herbal Alami}

Kegiatan penyuluhan dan pelatihan pembuatan handmade sabun herbal alami, merupakan tahapan kedua setelah dilaksanakannya virtual talkshow sebagai bentuk kegiatan yang bertujuan untuk membangun motivasi dan pola pikir milennialpreneur. Penyuluhan dan Pelatihan pembuatan handmade sabun herbal alami merupakan hasil dari ide kreatif berupa formulasi produk sabun kekinian dengan pemanfaatan herbal alami. Kegiatan dilaksanakan oleh Tim Lembaga Penelitian Pengembangan dan Pengabdian kepada Masyarakat (LP3M) Universitas Muhammadiyah Makassar. Pelaksanaannya kegiatan dilaksanakan secara virtual yang terdiri dari beberapa tahapan diantaranya sebagai berikut:

\section{Persiapan Kegiatan}

Persiapan yang dilakukan tim PKM Universitas Muhammadiyah Makassar antara lain mempersiapkan materi, video pembuatan sabun herbal alami, media virtual (zoom), link registrasi, undangan virtual, absensi, sertifikat peserta serta form penilaian umpan balik perserta terhadap pelaksanaan kegiatan. Persiapan kegiatan dilakukan untuk memastikan segala bentuk kelengkapan acara sehingga kegiatan dapat berjalan dengan lancar.

\section{Pelaksanaan Kegiatan}

Kegiatan penyuluhan dan pelatihan pembuatan handmade sabun herbal alami dilaksanakan pada hari Rabu 11Agustus 2021 pukul 10.30 wita - selesai melalui zoom meeting, kegiatan ini diikuti oleh 156 Milenial Muda Makassar yang sebagian besar merupakan mahasiswa. Adapun rundown acara sebagai berikut:

10.30 - 11.00 Registrasi peserta

11.00 - 11.10 Pembukaan oleh host

11.10 - 11.20 Sambutan Ketua Panitia

11.20 - 12.00 Penyuluhan Handmade sabun herbal alami

12.00 - 12.15 Sesi tanya jawab 


\section{Evaluasi Kegiatan}

Kegiatan yang dilaksanakan dievaluasi dengan membagikan google form kepada seluruh peserta penyuluhan dan pelatihan untuk mengetahui umpan balik yang diterima peserta mengenai manfaat dan tingkat keberhasilan kegiatan ini dalam meningkatkan kapasitas peserta dalam melihat potensi dan mengembangkan ide bisnis kreatif.

\section{Hasil dan Pembahasan}

\section{Penyuluhan}

Hasil dari kegiatan pengabdian masyarakat yang dilaksanakan oleh Tim Dosen Pertanian yang berkolaborasi dengan LP3M Universitas Muhammadiyah Makassar, mampu memberikan stimuli dan membangun potensi usaha milennial makassar melalui pengembangan produk dengan menuangkan ide dan kreatifitas dalam berkarya. Kegiatan Penyuluhan menyajikan materi mengenai pengertian, jenis, keunggulan, teknik pembuatan dan hal-hal penting yang perlu diperhatikan dalam menunjang keberhasilan pembuatan sabun herbal alami.

Menurut Standar Nasional Indonesia (SNI) tahun 1994 Sabun adalah sediaan pembersih kulit yang tidak menyebabkan iritasi dibuat melalui proses saponifikasi (Penyabunan) dengan mencampurkan lemak atau minyak dengan larutan alkali berbentuk padat, berbusa, dengan atau tanpa penambahan bahan lainnya. Sabun mandi merupakan garam logam alkali (biasanya natrium atau kalium) dari asam lemak. Sabun termasuk salah satu jenis surfaktan yang memiliki kemampuan mengangkat kotoran dari badan dan pakaian. Proses pembuatan handmade sabun herbal alami memiliki kemampuan membersihkan sama seperti sabun komersial pada umumnya. Sabun herbal alami diracik tanpa menggunakan bahan kimia berbahaya. Salah satu keunggulan dalam proses pembuatan handmade sabun herbal alami yakni lebih bersifat ramah lingkungan dan kita juga bisa mencampur berbagai herbal alami yang berkhasiat dan mencocokkan dengan kebutuhan jenis kulit sehingga dihasilkan jenis sabun yang tepat. Bukan hanya membersihkan, sabun handmade juga mengandung sekitar $25 \%$ gliserin. Gliserin bisa melembabkan dan melembutkan kulit, menyejukan dan meminyaki sel-sel kulit juga (Sukawaty et al. 2016).

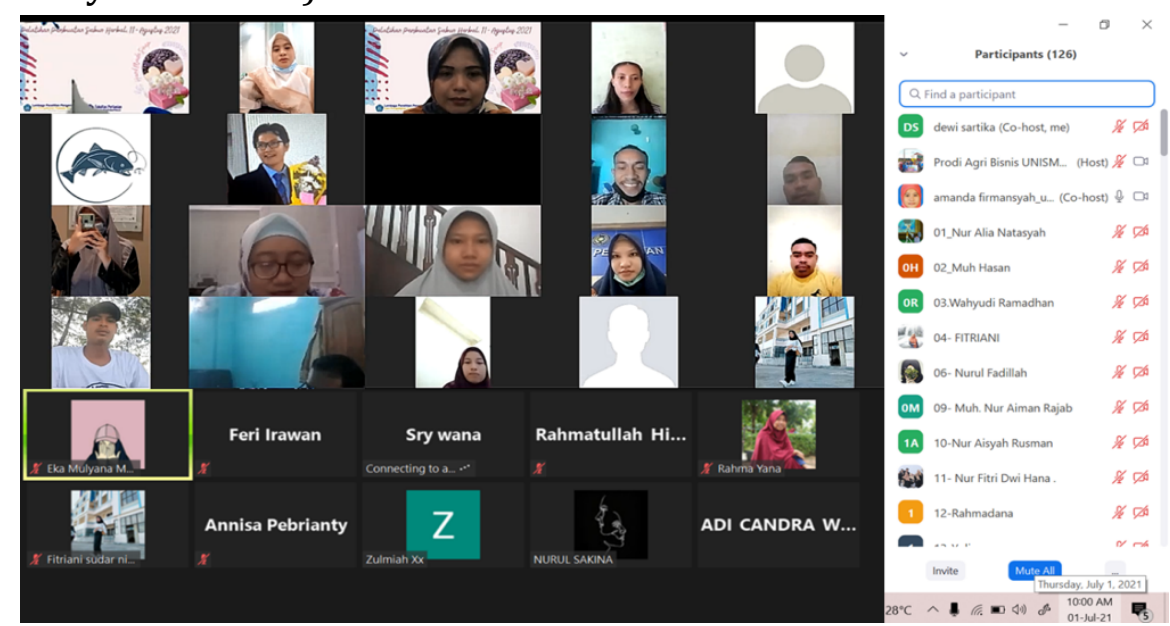

Gambar 1. Penyuluhan Handmade Sabun Herbal Alami dalam Berbagai Bentuk Kreasi Produk. 
Rangkuman kegiatan penyuluhan juga memberikan gambaran potensi pasar untuk usaha handmade sabun herbal alami yang secara luas dapat dipasarkan sebagai produk souvenir pada berbagai acara, sabun dengan efek aroma terapi yang diperuntukkan untuk penggunaan pada hotel, sebagai hampers, dan untuk pemakaian pribadi. Potensi ekonomi untuk usaha handmade sabun herbal alami juga memiliki nilai ekonomi yang tinggi, bahkan jika harganya sangat jauh berkali-kali lipat jika dibandingkan dengan jenis sabun bantangan yang telah lama dikomersialkan. Kisaran harga handmade sabun herbal alami yang dijual pada beberapa platform e-commerce sekitar Rp.20.000 sampai Rp42.000 untuk setiap batangnya.

\section{Pelatihan}

Kegiatan pelatihan pembuatan handmade sabun herbal alami dilaksanakan untuk meningkatkan keterampilan dan kreatifitas dalam membuat dan mengembangkan varian produk sabun herbal alami. Pada kegiatan pelatihan dilakukan dengan membuat 3 varian sabun herbal alami, antara lain; sabun sereh wangi, sabun mint dan juga sabun scrub kopi. Masing-masing varian dikembangkan dalam upaya menonjolkan sifat-sifat fungsioal dari herbal alami yang dikombinasikan dalam pembuatan sabun.

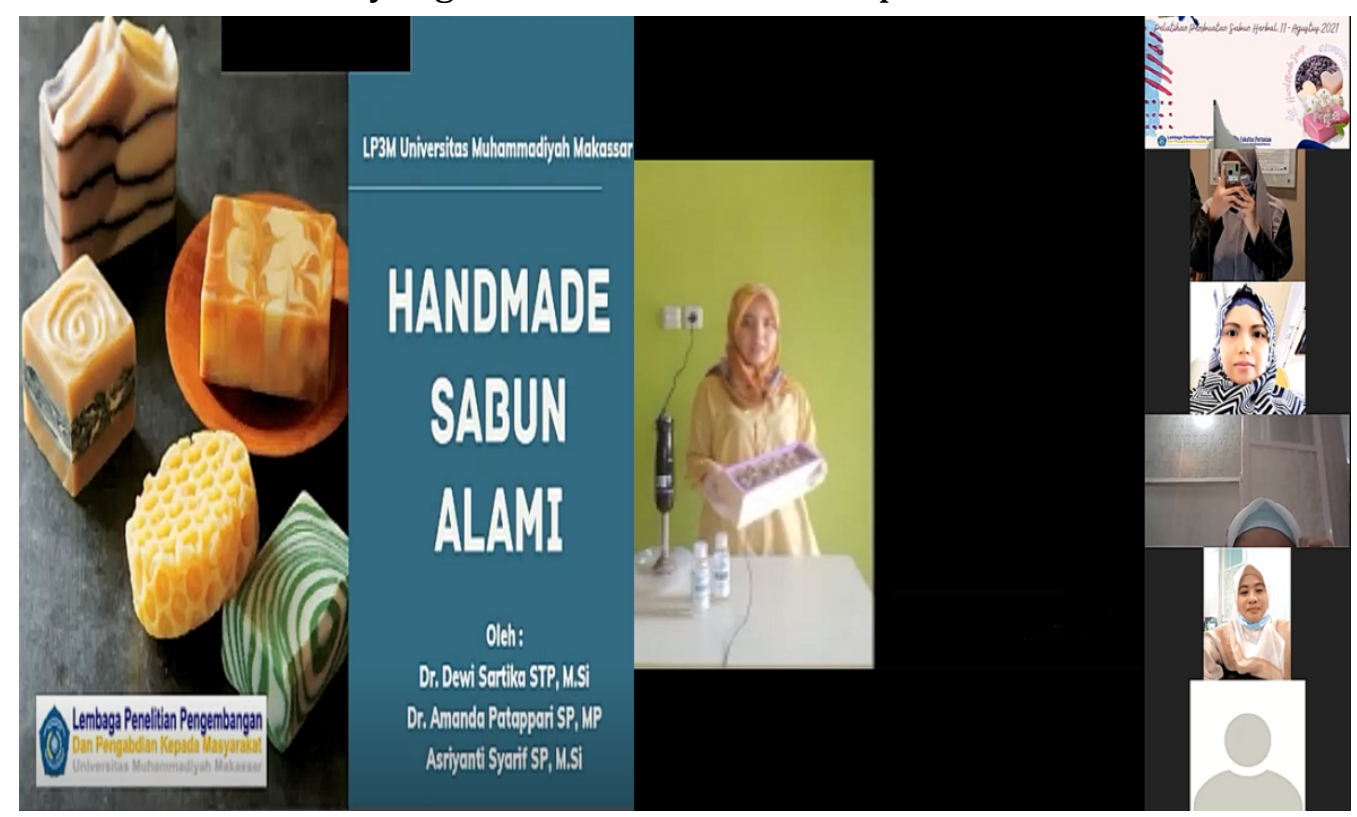

Gambar 2. Kegiatan Pelatihan Pembuatan Handmade sabun Herbal Alami

\section{Sabun sereh wangi}

Sereh wangi merupakan herbal alami yang banyak diaplikasikan dalam berbagai produk kebersihan, sereh wangi memiliki sifat fungsional sebagai antioksidan, antibakteri, antimikroba, dan juga antijamur (Shintawati dkk, 2020). Oleh sebab itu sereh wangi sangat baik digunakan pada produk sabun sebagai perawatan kulit alami. Selain manfaat sereh wangi yang menjadi pertimbangan banyak orang dalam menggunakan sabun herbal, aroma sabun dengan varian sereh wangi yang wangi dan khas rempah juga memberikan efek rileks bagi penggunanya (Sulaswatty dkk, 2019). Balitro (2020) juga memaparkan manfaat lain dari sabun sereh wangi untuk kulit antara lain; kandungan anti bakteri mampu menghilangkan gatal-gatal pada kulit yang disebabkan oleh biang keringat, eksim, panu, serta masalah kulit lainnya, ampuh mengatasi jerawat, mampu mencerahkan kulit, menghilangkan masalah bau badan, 
mencegah gigitan serangga, mengatasi masalah kaki pecah-pecah, selain itu, aroma sereh wangi mampu menyegarkan tubuh dan pikiran, memberikan rasa rileks dan menghilangkan rasa lelah setelah seharian beraktivitas.

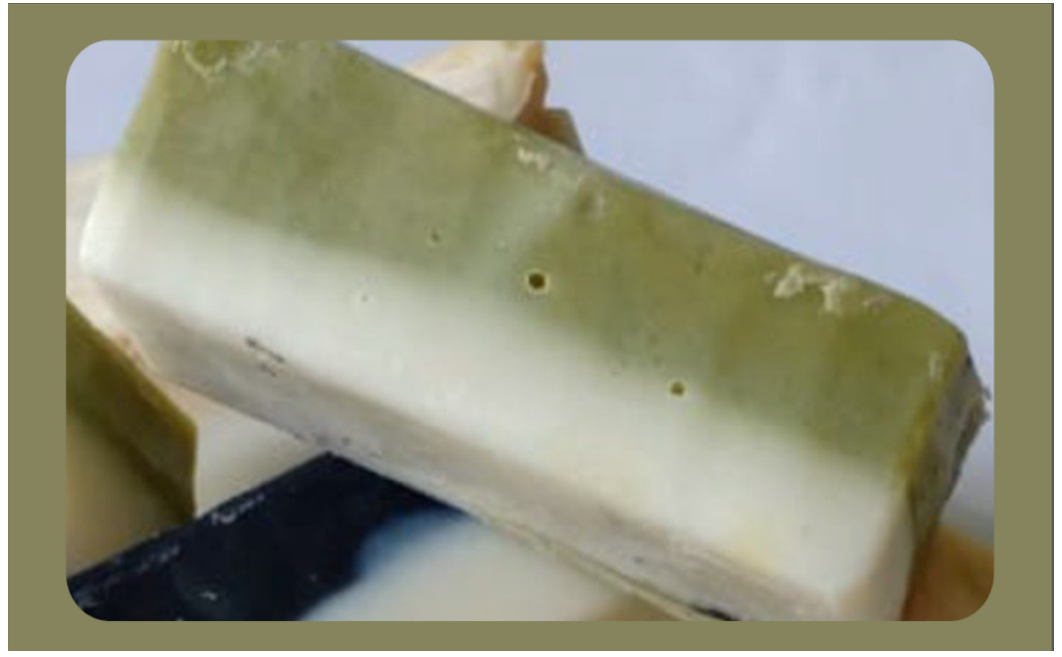

Gambar 3. Handmade Sabun Sereh Wangi

\section{Sabun Peppermint}

Minyak Peppermint yang diekstrak dari daun peppermint atau mentha piperita juga banyak diaplikasikan dalam membuat varian sabun mandi karena mampu memberikan sensasi segar dan menyejukkan. Minyak esensial peppermint pada sabun tidak hanya untuk membersihkan tubuh, menurut beberapa sumber literatur sabun minyak peppermint memiliki beberapa kegunaan berbeda antara lain: Minyak peppermint memiliki efek menenangkan yang membantu mengurangi peradangan pada saat terjadi alergi kulit, ruam, dan kulit terbakar (Ortega 2010), aktivitas antimikroba minyak peppermint membantu menghambat pertumbuhan bakteri di wajah (Li et al. 2011), sehingga membantu mengontrol jerawat dan mencegah penyumbatan pori-pori karena kelebihan sekresi minyak (Kumar et al. 2007).

Senyawa aktif yang terdapat dalam minyak mint antara lain; flavonoid, asam fenolat, mentol, asam kafeic, acetaldehyde, amyl alcohol, metal esters, limonene, ocimene, diterpen, gamma triterpen, steroid, fechene, kumarin, sitroneol, karoten, tokoferol, betaine, kolin, saponin dan tannin (Trevisan et al. 2017). Senyawa aktif pada minyak mint menghasilkan sifat fungsional tertentu seperti anti jamur, antivirus dan antibakteri (Saputra 2020).

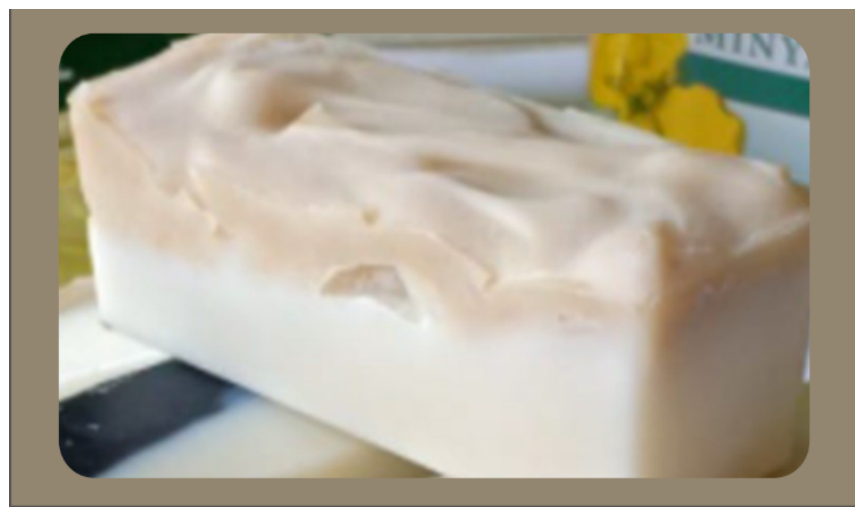

Gambar 4. Handmade Sabun Peppermint 


\section{Sabun Scrub Kopi}

Para peneliti dan praktisi perawatan kulit sama-sama telah menemukan bahwa biji kopi dalam berbagai bentuk produk seperti minuman atau diaplikasikan ke kulit melalui sabun, lotion, scrub, atau masker kopi memiliki segudang manfaat bagi kulit, hal ini disebabkan karena biji kopi termasuk sumber vitamin, nutrisi, dan antioksidan yang luar biasa. Biji kopi kaya akan antioksidan yang membantu melindungi kulit dari kerusakan akibat radikal bebas dan mencegah penuaan dini. Beberapa penelitian menunjukkan bahwa ekstrak kopi sangat baik digunakan sebagai bahan perawatan pada kulit karena secra fungsional memberikan sifat anti-penuaan karena dapat meningkatkan kolagen dan elastin, membuat kulit terlihat dan terasa lebih (Heffernan et al. 2009). Menggunakan sabun kopi dapat membantu mengurangi munculnya bintik, kemerahan, dan garis-garis halus. Sifat anti-inflamasi sabun kopi dapat dikaitkan dengan kandungan klorogenat serta melanoidin dalam kopi yang mampu mengurangi hiperpigmentasi (Fukushima et al. 2015). Selain itu ekstrak kopi merupakan sumber vitamin B3 atau niacin yang jika dikombinasikan dalam produk sabun sangat efektif dalam mencegah kanker kulit (Farah 2018). Sabun kopi juga dapat membantu menjaga kulit tetap terhidrasi dengan mengurangi kehilangan air transepidermal. Selain itu, telah terbukti memiliki kualitas antijamur dan antimikroba, yang menjadikannya pengobatan anti-jerawat.

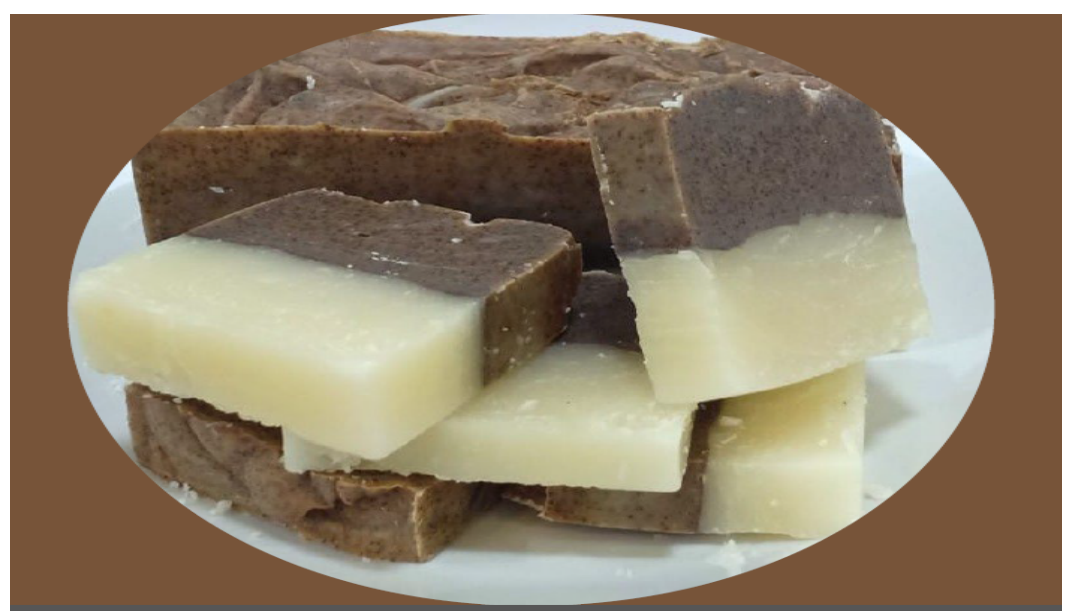

Gambar 5. Handmade Sabun Kopi

\section{Kesimpulan dan Saran}

Kesimpulan dari hasil dari pelaksanaan kegiatan penyuluhan dan pelatihan pembuatan handmade sabun herbal alami adalah:

1. Hasil survey kepuasan peserta menunjukkan bahwa kegiatan yang dilaksanakan sangat menarik, mampu mengembangkan ide kreatif dan bermanfaat bagi para peserta dalam menambah pengetahuan, pengalaman dan keterampilan menjadi millennialpreneur

2. Pelatihan ini sebagai sarana untuk membuka potensi pengembangan usaha handmade sabun herbal alami yang bernilai ekonomis. 
Adapun saran untuk tahap selanjutnya diperlukan kegiatan pendampingan terhadap pengembangan kelompok usaha rintisan millennial sebagai Langkah menjadi entrepreneur baik dari sisi manajemen bisnis, pengembangan produk dan pemasaran.

\section{Ucapan Terimakasih}

Terima kasih kepada Lembaga Penelitian dan Pengabdian Kepada Masyarakat (LP3M) Universitas Muhammadiyah Makassar atas dukungannya dalam mendanai pelaksanaan kegiatan Pengabdian Kepada Masyarakat (PKM).

\section{Referensi}

Dewan Standardisasi Nasional, 1994, Standar Mutu Sabun Mandi Padat, SNI 06-35321994, Departemen Perindustrian Nasional, Jakarta.

Farah A (2018) Nutritional and health effects of coffee. 259-290. https://doi.org/10.19103/as.2017.0022.14

Fukushima Y, Takahashi Y, Hori Y, et al (2015) Skin photoprotection and consumption of coffee and polyphenols in healthy middle-aged Japanese females. International Journal of Dermatology 54:410-418. https://doi.org/10.1111/ijd.12399

Hakim L (2015) Rempah \& Herba Kebun-Pekarangan Rumah Masyarakat, 1st edn. Diandra Creative (Kelompok Penerbit Diandra), Yogyakarta

Heffernan TP, Kawasumi M, Blasina A, et al (2009) ATR-Chk1 pathway inhibition promotes apoptosis after UV treatment in primary human keratinocytes: Potential basis for the uv protective effects of caffeine. Journal of Investigative Dermatology 129:1805-1815. https://doi.org/10.1038/jid.2008.435

Kumar G, Jayaveera K, Ashok Kumar C, et al (2007) Antimicrobial effects of Indian medicinal plants against acne-inducing bacteria Department of Pharmacognosy (. Tropical Journal of Pharmaceutical Research 6:717-723

Li J, Dong J, Qui JZ, et al (2011) Peppermint oil decreases the production of virulenceassociated exoproteins by staphylococcus aureus. Molecules 16:1642-1654. https://doi.org/10.3390/molecules16021642

Mulyani H, Widyastuti SH, Ekowati VI (2016) Tumbuhan herbal sebagai jamu pengobatan tradisional Terhadap penyakit dalam serat primbon jampi jawi jilid 1. Jurnal Penelitian Humaniora 21:73-91

Ortega (2010) ( 12 ) Patent Application Publication ( 10 ) Pub . No .: US 2010 / 0035098 A1 Patent Application Publication. 1:1-5

Saputra R (2020) MENARA Ilmu Vol. XIV No.01 April 2020. Lppm Umsb 121 XIV:121129

Sukawaty Y, Warnida H, Artha AV (2016) Formulasi Sediaan Sabun Mandi Padat Ekstrak Etanol Umbi Bawang Tiwai (Eleutherine bulbosa (Mill.) Urb.). Media Farmasi: Jurnal Ilmu Farmasi 13:14-22. https://doi.org/10.12928/mf.v13i1.5739 
Vol. 1. No. 4. Desember 2021

Trevisan SCC, Menezes APP, Barbalho SM, Guiguer ÉL (2017) Properties of Mentha Piperita: a Brief Review. World Journal of Pharmaceutical and Medical Research 3:309-313 